\title{
Nonsense Mutation R1162X of the Cystic Fibrosis Transmembrane Conductance Regulator Gene Does Not Reduce Messenger RNA Expression in Nasal Epithelial Tissue
}

\author{
Rossella Rolfini and Giulio Cabrini \\ Cystic Fibrosis Center, Ospedale Civile Maggiore, Verona, 37126 Italy
}

\begin{abstract}
Cystic fibrosis (CF) patients bearing the premature translation termination mutation (nonsense mutation) $\mathbf{W 1 2 8 2 X}$ present severe pulmonary and pancreatic disease, whereas patients carrying other nonsense mutations such as G542X, R553X, S1255X, R1162X, and W1316X show a severe pancreatic but mild pulmonary illness. CF gene expression was found absent in respiratory tissues with mutations $R 553 X$ and $W 1316 X$, which led to the hypothesis that the absence of the gene product in the lung is more favorable than the presence of an altered one. We asked whether or not all the nonsense mutations characterized by mild pulmonary disease phenotypes do present the absence of $\mathrm{CF}$ gene expression. We therefore investigated gene expression at the mRNA level in respiratory cells obtained from nasal polyps from a patient homozygous for the $\mathbf{R 1 1 6 2 X}$ mutation. Gene expression was studied by amplification with polymerase chain reaction of segments of the CF transmembrane conductance regulator cDNA that was obtained by reverse transcription of RNA. Semiquantitative analysis was performed by Northern analysis. By comparing the data obtained from polyps deriving from non-CF subjects and a $\mathrm{CF}$ patient homozygous for dF508 mutation, it is shown that no reduction of $\mathrm{CF}$ gene expression is evident in $\mathrm{R} 1162 \mathrm{X}$ respiratory tissue. We conclude that $\mathrm{CF}$ nonsense mutations have heterogeneous mechanisms of gene expression. (J. Clin. Invest. 1993. 92:2683-2687.) Key words: cystic fibrosis $\bullet$ reverse transcription • polymerase chain reaction • genotype $\bullet$ phenotype
\end{abstract}

\section{Introduction}

Cystic fibrosis $(\mathrm{CF})^{1}$ is the most common severe autosomal recessive disorder in Caucasians. The pathophysiology of the disease is associated with the abnormal regulation of epithelial chloride channels (1), which determines accumulation of vis-

This study has been presented in part at the 6th Annual North American Cystic Fibrosis Conference, Washington, DC, 15-18 October 1992.

Address reprint requests to Dr. Giulio Cabrini, Cystic Fibrosis Center, Ospedale Civile Maggiore, Piazzale Stefani 1, 37126 Verona, Italy.

Received for publication 24 November 1992 and in revised form 28 July 1993.

1. Abbreviations used in this paper: CF, cystic fibrosis; CFTR, cystic fibrosis transmembrane conductance regulator; RT, reverse transcription.

J. Clin. Invest.

(c) The American Society for Clinical Investigation, Inc.

$0021-9738 / 93 / 12 / 2683 / 05 \$ 2.00$

Volume 92, December 1993, 2683-2687 cous secretions in the lungs and pancreas and abnormal electrolyte composition in the sweat (2). CF is caused by mutations in the so-termed cystic fibrosis transmembrane conductance regulator (CFTR) gene, which encompasses 27 exons encoding a 1,480-amino acid protein (3-5). Structurally, CFTR is similar to the multidrug resistance P-glycoprotein, and is considered a member of the ATP-binding cassette superfamily of membrane transporters $(4,6)$. CFTR presents two ATP-binding sites, two transmembrane-spanning domains, and a regulatory domain, containing phosphorylation sites, which links the two halves of the protein (4). Several evidence point out that CFTR is a protein kinase-regulated $\mathrm{Cl}^{-}$channel (7-13).

So far 250 mutations have been identified in the CF gene (CF Genetic Analysis Consortium, unpublished data), and 27 of these (13\%) produce stop-codons (nonsense mutations). Patients bearing nonsense mutations, such as S1255X, G542X, G553X, and W1316X, present severe pancreatic insufficiency but mild to moderate pulmonary illness (14-17), whereas other patients carrying the W1282X present differences in the severity of lung involvement $(18,19)$. Pancreatic insufficiency and mild to moderate pulmonary disease have also been shown in patients homozygous for a very common nonsense mutation in northeastern Italy ( $10.2 \%$ of the CF chromosomes), which is $\mathrm{R} 1162 \mathrm{X}(20,21)$. This mutation is located in exon 19 between the second transmembrane domain and the second nucleotide binding fold, and it is characterized by the substitution of the amino acid arginine in position 1162 of CFTR with a UGA termination codon. So far there is no basis for claiming a relationship between the type of nonsense mutation and CF phenotype, which is a crucial question that has important implications on both drug and gene therapy.

There is evidence that suggests that the most common $\mathrm{CF}$ mutation, dF508, results in a defective processing and localization of the CFTR protein (22-27). It was shown that the basis of CFTR dF508 failure was due both to a decreased amount of the protein on the apical membrane and to the reduced time of opening of the mutated CFTR channel (28). However, not all mutations of CFTR affect protein processing. For instance, the missense mutation G551D, which is also in the nucleotide binding domain like dF508, produces a normally processed CFTR (22) with a severely reduced function (29). Therefore CFTR mutations can either cause a defective processing of CFTR or directly decrease CFTR function.

A third different mechanism of CFTR alteration has been suggested by studies on some nonsense mutations, namely G553X (exon 11) and W1316X (exon 21), in which severe reduction of CFTR mRNA and undetectable protein have been reported in respiratory cells $(30,31)$. Also, for nonsense mutations of CFTR, the mechanism is probably not univocal, owing to the controversial data presented on the $\mathrm{W} 1282 \mathrm{X} \mathrm{mu}-$ tation $(32,33)$. It is already known that in vivo nonsense mu- 
tations in genes of other human diseases lead either to decreased mRNA accumulation (34-36) or to normal mRNA levels with production of truncated protein (37-39). In both cases the molecular mechanism is not clearly understood.

In order to better understand the pathway by which CFTR nonsense mutations lead to the CF disorder, we investigated the effect of the nonsense mutation $\mathrm{R} 1162 \mathrm{X}$ on the expression of the CF gene. We analyzed the steady-state levels of CFTR mRNA in nasal polyps of a patient homozygous for R1162X, and we found a levels of transcript comparable to that detected in non-CF tissue.

\section{Methods}

Experimental subjects. Nasal polyps, excised to relieve airway obstruction, were obtained from a female CF patient homozygote for R $1162 \mathrm{X}$, a CF male homozygote for the phenylalanine deletion at codon 508 (dF508), and non-CF subjects. Tissue specimens were collected in the operating room immediately after the excision and placed in chilled Leibovitz-15 medium (ICN-Flow, Irvine, UK) for transport to the laboratory, where they were aliquoted, frozen in liquid nitrogen, and stored at $-80^{\circ} \mathrm{C}$ until use.

Cell culture. T84 colon carcinoma cells (CCL 248, American Type Culture Collection, Rockville, MD) were grown to confluence in DME (ICN-Flow) and Ham's F12 (1:1) (Sigma Chemical Co., St. Louis, MO) supplemented with 5\% FBS (ICN-Flow), 2 mM glutamine (ICNFlow), and $40 \mu \mathrm{g} / \mathrm{ml}$ gentamycin (Schering-Plough, Kenilworth, NJ). NIH 3T3 cells (American Type Culture Collection, CRL 1658) were grown to confluence in DME with $10 \% \mathrm{FBS}, 2 \mathrm{mM}$ glutamine, and 40 $\mu \mathrm{g} / \mathrm{ml}$ gentamycin. Cells were washed once with chilled PBS (ICNFlow) before the total RNA extraction.

White blood cell isolation. White blood cells were isolated from buffy coats obtained from peripheral blood of healthy volunteer and red blood cells were disrupted by hypotonic lysis.

$R N A$ extraction. Frozen polyps and washed cells were placed directly in the RNAzol B solution (Biotecx Laboratories, Inc., Houston, TX), and homogenized with few strokes in a glass-Teflon homogenizer (B. Braun, Melsungen, FRG). Total RNA was isolated according to the supplier's instructions, redissolved in RNase-free 1 mM EDTA, 10 $\mathrm{mM} \mathrm{NaCl}, 10 \mathrm{mM}$ Tris- $\mathrm{HCl}$ (Carlo Erba, Milan, Italy) pH 8.0 solution, and measured by ultraviolet (UV) spectrophotometry. The quality of the extracted samples was also assessed in a nondenaturing $1.2 \%$ agarose (Sigma Chemical Co.) $/ 89 \mathrm{mM}$ Tris-borate, $89 \mathrm{mM}$ boric acid, 2 mM EDTA (Carlo Erba) gel electrophoresis (40) by visual examination of ethidium bromide-stained $18 \mathrm{~s}$ and $28 \mathrm{~s}$ ribosomal fractions as undegraded bands.

cDNA synthesis and PCR amplification. CDNA was synthesized by reverse transcription (RT) of total RNA and subsequently amplified in a single tube reaction by using the GeneAmp RNA PCR Kit and method (Perkin Elmer Cetus, Norwalk, CT). Briefly, $3 \mu \mathrm{g}$ of total RNA suspended in $2 \mu \mathrm{l}$ of $10 \mathrm{mM}$ Tris- $\mathrm{HCl}, 10 \mathrm{mM} \mathrm{NaCl}$, and $1 \mathrm{mM}$ EDTA was added to $4 \mu \mathrm{l}$ of $25 \mathrm{mM} \mathrm{MgCl}, 2 \mu \mathrm{l}$ of $500 \mathrm{mM} \mathrm{KCl} / 100$ mM Tris- $\mathrm{HCl}$ ( $10 \times$ PCR buffer II), $1 \mu \mathrm{l}$ of sterile water, $2 \mu \mathrm{l}$ of $10 \mathrm{mM}$ (each) dNTP, $20 \mathrm{U}$ of RNase inhibitor in $1 \mu \mathrm{l}, 50 \mathrm{U}$ of cloned Moloney murine leukemia virus reverse transcriptase in $1 \mu \mathrm{l}$, and $1 \mu \mathrm{l}$ of $50 \mu \mathrm{M}$ random hexamers. To reduce evaporation the reaction mixture was overlayed with $50 \mu \mathrm{l}$ of mineral oil (Perkin Elmer Cetus, Norwalk, CT). The reaction tube was incubated at room temperature for $10 \mathrm{~min}$, then in a Perkin-Elmer Cetus DNA thermal cycler at $42^{\circ} \mathrm{C}$ for $90 \mathrm{~min}$, $99^{\circ} \mathrm{C}$ for $5 \mathrm{~min}$, and $5^{\circ} \mathrm{C}$ for $5 \mathrm{~min}$. The synthesized cDNA was amplified by adding $4 \mu \mathrm{l}$ of $25 \mathrm{mM} \mathrm{MgCl}_{2}, 8 \mu \mathrm{l}$ of $10 \times$ PCR buffer II, $65.5 \mu \mathrm{l}$ of sterile water, $2.5 \mathrm{U}$ of AmpliTaq DNA polymerase in $0.5 \mu \mathrm{l}$, and $1 \mu \mathrm{l}$ of each primer $(15 \mathrm{mM})$. In order to exclude the presence of contaminants in the reagents, two negative controls were included, both in RT (water replacing RNA) and in the PCR amplification (water replacing cDNA). Fragments of CFTR cDNA from exons 5-7, and from exons 20-24 were generated by using sets of primers consisting respectively of the sequences: 5'-ACTTTAAAGCTGTCAAGCCGTG-3' (sense) and 5'-CTGTATTTTGTTTATTGCTCCAA-3' (antisense), 5'-AAACTCGAGGATCGATGGTGTGTCTTGGGATTC-3'(sense)and 5'-AACTGCAGCTAAAGCCTTGTATCTTGCACCTCTTC-3' (antisense) (41). PCR amplification has been done by the following program: 30 repeated cycles, including $1 \mathrm{~min}$ of denaturation at $94^{\circ} \mathrm{C}, 1 \mathrm{~min}$ of annealing at $55^{\circ} \mathrm{C}, 1 \mathrm{~min}$ of extension at $72^{\circ} \mathrm{C}(41)$. To check for the quality of the RNA samples, we synthesized a set of primers to amplify a 523-bp fragment of human $\beta$-actin gene (41); their sequences were 5'-CATCGAGCACGGCATCGTCA-3' (sense) and 5'-GTCAGGCAGCTCGTAGCTCT-3' (antisense) and they worked at the same PCR conditions of 5-7, 20-24 CFTR primers. To confirm the epithelial origin of the mRNA, a 588-bp fragment of the human cytokeratin 15 (HCK 15) was amplified ( 30 ) with the following steps of PCR reaction: after $6 \mathrm{~min}$ of denaturation at $94^{\circ} \mathrm{C}, 30$ cycles of $45-\mathrm{s}$ denaturation at $94^{\circ} \mathrm{C}, 45-\mathrm{s}$ annealing at $58^{\circ} \mathrm{C}, 60$-s extension at $72^{\circ} \mathrm{C}$; a final polymerization was carried out at $72^{\circ} \mathrm{C}$ for $10 \mathrm{~min}$. HCK-15 primer sequences are: 5'-TGAAGGAGTTCAGCAGCCAGCTGG-3' (sense) and 5'-ACTGACTCTTCTACATTGATGTGG-3'. All primers were prepared with a model 392 DNA/RNA synthesizer (Applied Biosystems, Inc., Foster City, CA ). $10 \mu l$ of each amplified cDNA sample was electrophoresed on $1 \%$ SeaKem GTG agarose (FMC Corp., Rockland, ME) ethidium bromide gel and photographed on a UV transilluminator (LKB-Pharmacia, Uppsala, Sweden). A 1-kb DNA ladder (Bethesda Research Laboratories, Life Technologies, Inc., Gaithersburg, MD) was used to determine the correct size of the produced fragments.

Restriction enzyme digestion. $10 \mu \mathrm{l}$ of amplified CFTR cDNA fragments was digested with $20 \mathrm{U}$ of appropriate restriction enzymes using protocols recommended by the manufacturer (Promega Corp., Madison, WI). Electrophoresis of digested cDNA fragments was carried out in a $2 \%$ Nusieve / $1 \%$ SeaKem agarose (FMC Corp.) ethidium bromide gel. A 1-kb DNA ladder has been used for size determination.

Northern analysis. $30 \mu \mathrm{g}$ of denatured total RNA was electrophoresed for 5-6 h at $10 \mathrm{~V} / \mathrm{cm}$ on $1.5 \%$ agarose gels containing $2.2 \mathrm{M}$ formaldehyde, $20 \mathrm{mM}$ Mops, $\mathrm{pH}$ 7.0, $8 \mathrm{mM}$ sodium acetate, and $1 \mathrm{mM}$ EDTA (42). $90 \mu \mathrm{g} / \mathrm{ml}$ ethidium bromide was added to the samples before electrophoresis in order to assess the quality and the amounts of RNA in each lane by visual examination of ribosomal RNA fractions. As a molecular weight marker $3 \mu \mathrm{g}$ of a $0.24-9.5$-kb RNA ladder (Gibco BRL, Gaithersburg, MD) was loaded into the gels. The RNA was transferred to Hybond-C extra supported nitrocellulose membranes (Amersham International, Amersham, UK) by capillary blotting (42) for 15-16 $\mathrm{h}$ and immobilized on the membrane by incubation at $80^{\circ} \mathrm{C}$ for $2 \mathrm{~h}$. The filters were prehybridized for $8 \mathrm{~h}$ at $42^{\circ} \mathrm{C}$ in a solution containing $50 \%$ formamide ( $\mathrm{vol} / \mathrm{vol}$ ), $5 \times$ Denhardt's, $0.5 \%$ $\mathrm{SDS}, 5 \times \operatorname{SSPE}(0.9 \mathrm{M} \mathrm{NaCl}, 50 \mathrm{mM}$ sodium phosphate, $\mathrm{pH} 7.4,5 \mathrm{mM}$ EDTA), and $250 \mu \mathrm{g} / \mathrm{ml}$ denatured salmon sperm DNA (Sigma Chemical Co.). The prehybridization mixture was replaced with fresh solution containing $2 \times 10^{6} \mathrm{cpm} / \mathrm{ml}$ of ${ }^{32} \mathrm{P}$-labeled C1-1/5 CFTR cDNA probe (4) (American Type Culture Collection 61160, Rockville, MD) with a specific activity of $1.9 \times 10^{9} \mathrm{cpm} / \mu \mathrm{g}$. This probe, spanning exons 9-24 of CFTR cDNA, was radiolabeled with $\left[\alpha-{ }^{32} \mathrm{P}\right] \mathrm{dCTP}$ (3,000 Ci/mmol; Amersham International) by random priming using the Multiprime DNA labeling system kit according to the manufacturer's conditions (Amersham International). Hybridization was performed overnight at $42^{\circ} \mathrm{C}$ and then the blots were washed twice in $2 \times$ SSC $(1 \times=0.15 \mathrm{M} \mathrm{NaCl}, 15 \mathrm{mM}$ sodium citrate, $\mathrm{pH} 7.4)$ solution containing $0.1 \%$ of SDS at room temperature for $10 \mathrm{~min}$, followed by two washings in $0.5 \% \mathrm{SSC}, 0.1 \% \mathrm{SDS}$ at $65^{\circ} \mathrm{C}$ for $30 \mathrm{~min}$, with continuous shaking. The colon carcinoma cell line T84 was used as a positive control for CFTR mRNA expression. Human $\beta$-actin probe cDNA (43) that hybridized to a $2.0-\mathrm{kb} \beta$-actin mRNA was used as a control probe and to estimate the RNA blotted on the filter. Membranes were exposed to Hyperfilm-MP films (Amersham International) at $-80^{\circ} \mathrm{C}$ with intensifying screens. Laser densitometry, using a model $2202 \mathrm{Ul}$ troscan (LKB-Pharmacia) was used to quantitate the relative signal intensity of the bands obtained and normalized on the basis of $\beta$-actin mRNA signal to correct for RNA loading. 


\section{Results}

The expression of CFTR mRNA was initially studied by reverse transcription and PCR amplification. Two sets of primers amplifying fragments of CFTR cDNA spanning exons 5-7 and exons 20-24 were utilized in nasal polyps obtained from one patient homozygous for dF508, one patient homozygous for $\mathrm{R} 1162 \mathrm{X}$, and a non-CF subject. To confirm the specificity of the amplification of CFTR, RNA extracted from NIH 3T3 fibroblasts, in which CFTR is not expressed, was included. Fig. $1 A$ shows the presence of amplified fragments of the expected size from exons 5-7. The signal of the R1162X and dF508 samples is present and comparable to that of the non-CF polyp while no signal was detectable from the NIH 3T3 sample. The same results were observed utilizing the $20 / 24$ primers, as shown in Fig. $1 B$. To increase confidence that our primers were amplifying the expected fragments, restriction enzymes were used to cut the amplified product derived from the R1162X samples. Bands of the appropriate size were detected after digestion with Dde I (297, 180, $135 \mathrm{bp})$ and Hinf I ( 395 , $104,98 \mathrm{bp}$ ), giving further evidence to the specificity of the signal.

Since the nasal polyp is a dishomogeneous tissue, the expression of the human cytokeratin 15 (HCK15) RNA was checked to assess the epithelial origin of the RNA samples. We have chosen HCK 15 as an epithelial marker, because the epithelial components of nasal polyps are very similar to those present in trachea (44) where HCK 15 is expressed in substantial quantities (45). HCK 15 is clearly expressed in all the polyp samples, as described in Fig. $2 \mathrm{~A}$. In the same experiment no signal was detectable from white blood cell RNA that was used as an additional negative control for the primers. Therefore we can assume that our total RNA is at least in part deriving from respiratory epithelium. Since inflammatory cells deriving from circulating white blood cells could infiltrate the nasal polyp tissue and CFTR mRNA was detected also in lymphocytes by PCR amplification (46), we wanted to exclude that the primers utilized for the amplification of CFTR cDNA were detecting a

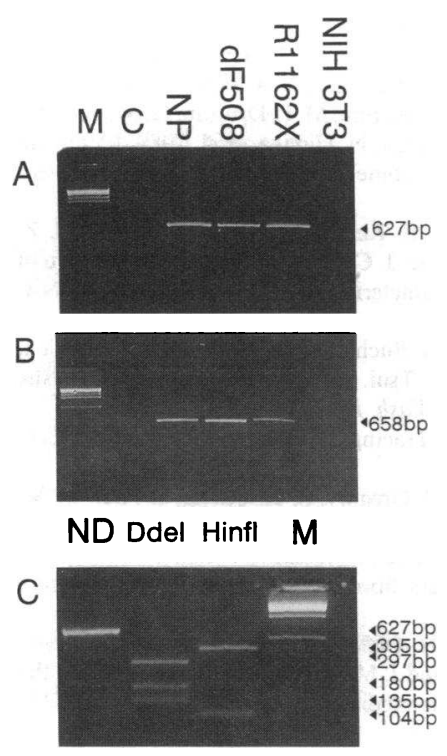

Figure 1. Ethidium bromide staining of the PCR-amplified cDNA derived from nasal polyps. $M$ is the $1-\mathrm{kb}$ DNA ladder size marker; $C$ is negative control (water instead of RNA in $\mathrm{RT}$ and amplification reactions). (A) Amplification of CFTR cDNA from exons 5-7. NP is polyp sample from a non-CF subject; dF508 is polyp sample from a dF508 homozygote. $R 1162 \mathrm{X}$ is polyp sample from a R1162X homozygote. NIH 3T3 is sample from murine fibroblasts. $(B)$ Amplification of CFTR CDNA from exons 20-24. Same symbols as in $A$. $(C)$ Digestion of the cDNA amplified from exons 5-7 of the polyp sample of the $\mathrm{R} 1162 \mathrm{X}$ patient. ND is not digested fragment. Dde I and Hinf I indicate the products of digestion with the two restriction enzymes.

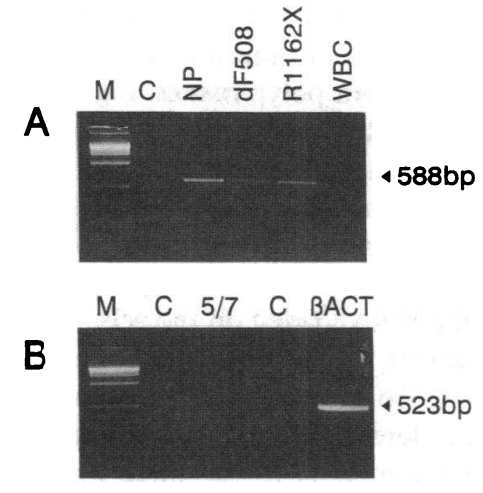

Figure 2. Ethidium bromide staining of the PCRamplified cDNA derived from nasal polyps and white blood cells. $M$ is $1-k b$ ladder size marker. $\mathrm{C}$ is negative control (water instead of RNA in reverse transcription and amplification reactions). ( $A$ ) Amplification with human cytokeratin 15 primers. NP is polyp sample from a nonCF subject. dF508 is polyp sample from a dF508 homozygote. $\mathrm{R} 1162 \mathrm{X}$ is polyp sample from $\mathrm{R} 1162 \mathrm{X}$ homozygote. WBC is sample from peripheral blood leukocytes. (B) Amplification of CFTR cDNA with primers from exons 5-7

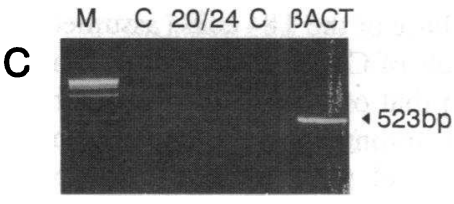

$(5 / 7)$ and of human $\beta$-actin cDNA ( $B A C T)$ in peripheral leucocytes. $(C)$ Amplification of CFTR cDNA with primers from exons 20-24 $(20 / 24)$ and of human $\beta$-actin cDNA $(B A C T)$ in peripheral leucocytes.

signal coming from white blood cells. The same primers and protocols were adopted to amplify the cDNA obtained by reverse transcription of $3 \mu \mathrm{g}$ of RNA extracted from circulating leukocytes. Fig. 2, $B$ and $C$, demonstrates that no signal from CFTR is apparent from leukocytes. To check the quality of the RNA, primers to human $\beta$-actin were used and fragments of the expected size were obtained. Therefore we can assume with good confidence that the signal corresponding to CFTR mRNA in the polyp was not derived from leukocytes infiltrating the tissue.

The protocol adopted in the previous PCR experiments does not allow a reliable quantitative evaluation of the amount

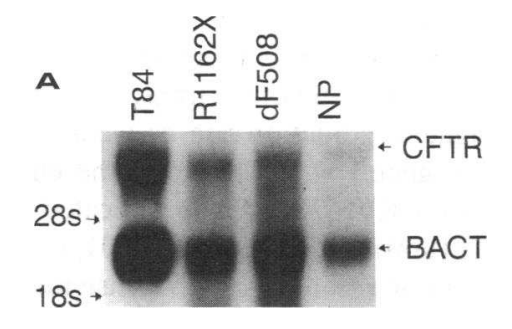

Figure 3. Northern analysis of total RNA. $(A)$ Blots were hybridized with C1-1/ 5 CFTR probe and with human $\beta$-actin probe. NP is polyp sample from a non-CF subject, dF508 from a dF508 homozygote, R1162X from a R1162X homozygote. T84 is from a sample of T84 cells. CFTR and BACT indicate the position of the CFTR mRNA $(6.5 \mathrm{~kb})$ and of $\beta$-actin $(2.0 \mathrm{~kb})$ calculated from the migration of 9.5-0.25 RNA ladder size marker. $28 \mathrm{~s}$ and $18 \mathrm{~s}$ indicate the level of CFTR mRNA expression in the same samples. Data are normalized to the level of T84 cells that was equal to 1 . Mean and SD are reported $(n=3)$. 
of CFTR mRNA expressed in the nasal polyps of the three different genotypes. For this reason a Northern analysis was performed on the RNA extracted from polyp tissues. Fig. $3 \mathrm{~A}$ confirms the presence of CFTR mRNA in all three samples. The data are validated by the detection of the expected $6.5-\mathrm{kb}$ CFTR mRNA size that was clearly expressed in the T84 colon carcinoma cell line. The blots were simultaneously hybridized with a human $\beta$-actin probe to check for the RNA integrity and to correct for the amount of the RNA loaded on the gels.

Autoradiographs were scanned with a laser densitometer and the optical density deriving from CFTR was normalized with that of $\beta$-actin among the different samples. Fig. $3 B$ shows the relative expression of CFTR mRNA in the three polyp samples in comparison to that of the T84 cells. Normalizing the optical density values to those of the T84 cells (assumed as value 1), the steady-state levels of CFTR mRNA in the three polyp tissues were lower than that of T84 cells and no significant difference was observed among the polyps of the three investigated genotypes (normal polyp $0.42 \pm 0.12$, dF508 polyp $0.33 \pm 0.18, \mathrm{R} 1162 \mathrm{X} 0.58 \pm 0.35$, mean $\pm \mathrm{SD}, n=3)$. Therefore we ruled out either the absence or the reduction of the expression of CFTR mRNA in presence of this type of nonsense mutation.

\section{Discussion}

Our data on the nonsense mutation R $1162 \mathrm{X}$ clearly show that the CFTR mRNA is expressed to the same extent both in the $\mathrm{CF}$ and non-CF respiratory nasal epithelia, as demonstrated by RT-PCR and Northern analysis. In contrast, it has been already shown that the nonsense mutations $\mathrm{R} 553 \mathrm{X}$ and W1316X determine severe reduction of CFTR mRNA (30).

Nonsense mutations have sometimes been associated with lack of mRNA and protein, as in human $\beta$-globin (34), human $\alpha 1$-antitrypsin (35), and insulin receptor (36) genes, while in other cases such as that of the LDL receptor or the apolipoprotein C-II genes a stable truncated protein is synthesized (37, 39 ). It has been suggested that mRNAs presenting translation termination mutations might be unstable since they may not be protected by ribosomes from the endogenous RNAase digestion (34). On the contrary, mRNAs with premature termination codons located toward the $3^{\prime}$ end of the transcript sometimes seem to escape the higher degradation rate, as occurs with the dihydrofolate reductase gene (47). Therefore, the effect produced by CFTR mutation R1162X, which is located toward the 3 ' end of the gene (amino acid 1162 of 1480), could be consistent with this latter condition. Since nonsense mutation W1316X, which is even more toward the $3^{\prime}$ end, is characterized by a lack of mRNA, one might speculate that conformational modifications of the mRNA specific to each mutation rather than to the position of the mutation itself in the gene are responsible for the protection from RNAse digestion of the transcript.

These data may contribute to the further understanding of the molecular mechanisms by which mutations of CFTR gene eventually lead to defective chloride transport in CF epithelial cells. It is now known that CFTR protein is abnormally processed in the presence of deletion or missense mutations as it occurs with dF508, dI507, and S549I (22). On the contrary, a mature protein is present in the mutation G551D (22), in which a defective function is the molecular basis of the defect (29). Nonsense mutations of CFTR might therefore cause the cellular defect either because of absence of the protein, as in R553X and W1316X (31), or possibly because of the presence of a truncated protein as could be hypothesized for the R1162X mutation.

Whether this putative truncated protein lacking the second nucleotide binding domain (NBD2) results in the cellular defect because of protein instability, altered processing, or reduced function is not yet understood. Even if the influence of genotype on phenotype is very controversial in this disease (48), it is noteworthy to mention that patients homozygous for the $\mathrm{R} 1162 \mathrm{X}$ mutation present defective pancreatic function but mild to moderate lung disease (20). In parallel with data demonstrated in mutations characterized by a mild pulmonary phenotype such as G551S (29), it is possible that R1162X might express a partially functional protein, at least in the respiratory epithelia. We checked protein expression in the same nasal tissues by immunoprecipitation and Western analysis, but the level of protein in non-CF samples is below detectability (data not shown).

In conclusion, the mutation $\mathrm{R} 1162 \mathrm{X}$ results in normally expressed CFTR mRNA, indicating that nonsense mutations of the CFTR gene have heterogeneous mechanisms of mRNA processing (e.g., degradation). The presence of the transcript in respiratory cells of patients with mild to moderate lung disease could suggest that a partially functional protein could be expressed at least in the airway tract.

\section{Acknowledgments}

We are grateful to Dr. Anna Tamanini for experiments on CFTR protein expression, Prof. Gianni Mastella for support and encouragement, Dr. Chiara Gamberi for helpful suggestions, Prof. Giorgio Berton for revising the manuscript, Prof. Carlo Morandi, Drs. Paolo Gasparini, Cristina Accordini, Carlo Zancanaro, and Cristina Dechecchi for stimulating discussions, Mr. Valentino Stanzial for oligonucleotides synthesis, and the Department of Otolaryngology, which made possible the collection of tissue.

\section{References}

1. Quinton, P. M. 1990. Cystic fibrosis: a disease in electrolyte transport. FASEB J. 4:2709-2717.

2. Boat, T. F., M. J. Welsh, and A. L. Beaudet. 1989. Cystic fibrosis. In The Metabolic Basis of Inherited Disease. 6th edition. C. L. Scriver, A. L. Beaudet, W. S. Sly, and D. Valle, editors. McGraw-Hill, Inc., New York. 2649-2680.

3. Rommens, J. M., M. C. Iannuzzi, B. Kerem, M. L. Drumm, G. Melmer, M. Dean, R. Rozmahet, J. L. Cole, D. Kennedy, N. Hidaka, et al. 1989. Identification of the cystic fibrosis gene: chromosome walking and jumping. Science (Wash. DC). 245:1059-1065.

4. Riordan, J. R., J. M. Rommens, B. Kerem, N. Alon, R. Rozmaehl, Z. Grzelczak, J. Zielensky, S. Lok, N. Plavsic, J. Chou, et al. 1989. Identification of the cystic fibrosis gene: cloning and characterization of complementary DNA. Science (Wash. DC). 245:1966-1073.

5. Kerem, B. S., J. M. Rommens, J. A. Buchanan, D. Markiewicz, T. K. Cox, A. Chakravarti, M. Buchwald, and L.-C. Tsui. 1989. Identification of the cystic fibrosis gene: genetic analysis. Science (Wash. DC). 245:1073-1080.

6. Jan, L. Y., and Y. N. Jan. 1992. Tracing the roots of ion channels. Cell. 69:715-718.

7. Rich, D. P., M. P. Anderson, R. J. Gregory, S. H. Cheng, S. Paul, D. M Jefferson, J. D. McCann, K. W. Klinger, A. E. Smith, and M. J. Welsh. 1990. Expression of cystic fibrosis transmembrane conductance regulator corrects defective chloride channel regulation in cystic fibrosis airway epithelial cells. Nature (Lond.). 347:358-363.

8. Drumm, M. L., H. A. Pope, W. H. Cliff, J. M. Rommens, S. A. Marvin, L. C. Tsui, F. S. Collins, R. A. Frizzell, and J. M. Wilson. 1990. Correction of the cystic fibrosis defect in vitro by retrovirus-mediated gene transfer. Cell. 62:12771233.

9. Anderson, M. P., D. P. Rich, R. J. Gregory, A. E. Smith, and M. J. Welsh. 1990. Generation of cAMP-activated Chloride currents by expression of CFTR. Science (Wash. DC). 251:679-682. 
10. Kartner, N., J. W. Hanrahan, T. J. Jensen, A. L. Naismith, S. Sun, C. A. Ackerley, E. F. Reynes, L. C. Tsui, J. M. Rommens, C. E. Bear, et al. 1991. Expression of the cystic fibrosis gene in non-epithelial invertebrate cells produces a regulated anion conductance. Cell. 64:681-691.

11. Anderson, M. P., R. J. Gregory, S. Thompson, D. W. Souza, S. Paul, R. L. Mulligan, A. E. Smith, and M. J. Welsh. 1991. Demonstration that CFTR is a chloride channels by alteration of its anion selectivity. Science (Wash. DC). 253:202-205.

12. Bear, C., F. Duguay, A. L. Naismith, N. Kartner, J. W. Hanrahan, and J. R. Riordan. 1991. $\mathrm{Cl}^{-}$channel activity in Xenopus oocytes expressing the cystic fibrosis gene. J. Biol. Chem. 266:19142-19145.

13. Bear, C. E., C. Li, N. Kartner, R. J. Brigdes, T. J. Jensen, M. Ramjeesingh, and J. R. Riordan. 1992. Purification and functional reconstitution of the cystic fibrosis transmembrane conductance regulator. Cell. 68:809-818.

14. Cutting, G. R., L. M. Kasch, B. J. Rosenstein, L. C. Tsui, H. H. Kakazian and S. E. Antonarakis. 1990. Two patients with cystic fibrosis nonsense mutations in each cystic fibrosis gene, and mild pulmonary disease. N. Engl. J. Med. 323:1685-1689.

15. Cuppens, H., P. Marynen, C. Ce Boeck, F. De Baewts, E. Eggermont, H. Van den Beghe, and J. J. Cassiman. 1990. A child, homozygous for a stop mutation in exon 11, shows milder cystic fibrosis symptoms than her heterozygous nephew. J. Med. Genet. 27:717-719.

16. Beaudet, A. L., R. G. Perciaccante, and G. R. Cutting. 1991. Homozygous nonsense mutation causing cystic fibrosis with uniparental disomy. Am. J. Hum. Genet. 48:1213.

17. Cheadle, J., L. Aljader, M. Goodchild, and A. L. Meredith. 1992. Mild pulmonary disease in a cystic fibrosis child homozygous for R553X. J. Med. Genet. 29:597.

18. Shoshani, T., A. Augarten, E. Gazit, N. Bashan, Y. Yahav, Y. Rivlin, A. Tal, H. Seret, L. Yaar, E. Kerem, et al. 1992. Association of a nonsense mutation (W1282X), the most common mutation in the Ashkenazi jewish cystic fibrosis patients in Israel, with presentation of severe disease. Am. J. Hum. Genet. 50:222:228

19. Feldmann, D., E. Thioulouse, A. Grimfeld, P. Majdalani, and P. Aymard. 1992. Characterization of the W1282X mutation in a french population. MP 99. Proceedings of XIth International Cystic Fibrosis Congress. Trinity College, Dublin, Ireland. (Abstr.)

20. Gasparini, P., G. Borgo, G. Mastella, A. Bonizzato, M. Dognini, and P. F. Pignatti. 1992. Nine cystic fibrosis patients homozygous for the CFTR nonsense mutation R1162X have mild or moderate lung disease. J. Med. Genet. 29:558562.

21. Gasparini, P., V. Nunes, A. Savoia, M. Dognini, N. Morral, A. Gaona, A. Bonizzato, M. Chillon, F. Sangiuolo, G. Novelli, et al. 1991. The search for south european cystic fibrosis mutations: identification of two new mutations, four variants, and intronic sequences. Genomics. 10:193-200.

22. Cheng, R. J., Gregory, J. Marshall, S. Paul, D. W. Souza, G. A. White, C. R. O'Riordan, and A. E. Smith. 1990. Defective intracellular transport and processing of CFTR is the molecular basis of most cystic fibrosis. Cell. 63:827834.

23. Gregory, R. J. S. H., D. P. Rich, S. H. Cheng, D. W. Souza, S. Paul, P. Manavalan, M. P. Anderson, M. J. Welsh, and A. E. Smith. 1991. Maturation and function of cystic fibrosis transmembrane conductance regulator variants bearing mutations in putative nucleotide-binding domains 1 and 2. Mol. Cell. Biol. 11:3886-3893.

24. Sarkadi, B., D. Bauzon, W. R. Huckle, H. S. Earp, A. Berry, H. Suchindran, E. M. Price, J. C. Olsen, R. C. Boucher, and G. A. Scarborough. 1992. Biochemical characterization of the cystic fibrosis transmembrane conductance regulator in normal and cystic fibrosis epithelial cells. J. Biol. Chem. 267:20872095.

25. Kartner, N., O. Augustinas, T. J. Jensen, A. L. Naismith, and J. R. Riordan. 1992. Mislocation of deltaF508 CFTR in cystic fibrosis sweat gland. Nature Genet. 1:321-327.

26. Dalemans, W. J. Hinnransky, P. Slos, D. Deyer, C. Fuchey, A. Pavirani, and E. Puchelle. 1992. Immunocytochemical analysis reveals differences between the subcellular localization of normal and dF508 recombinant cystic fibrosis transmembrane conductance regulator. Exp. Cell. Res. 201:235-240.

27. Denning, G. M., L. S. Ostedgaard, and M. J. Welsh. 1992. Abnormal localization of cystic fibrosis transmembrane regulator in primary cultures of cystic fibrosis airway epithelia. J. Cell Biol. 118:551-559.

28. Dalemans, W., P. Barbry, G. Champigny, S. Jallat, K. Dott, D. Dreyer,
R. G. Crystal, A. Pavirani, J. P. Lecocq, and M. Lazdunski. 1991. Altered chloride ion channel kinetics associated with the dF508 cystic fibrosis mutation. $\mathrm{Na}$ ture (Lond.). 354:526-528.

29. Drumm, M. L., D. J. Wilkinson, L. S. Smit, R. T. Worrell, T. V. Strong, R. A. Frizzell, D. C. Dawson, and F. S. Collins. 1991. Chloride conductance expressed by dF508 and other mutant CFTRs in Xenopus oocytes. Science (Wash. DC). 254:1797-1799.

30. Hamosh, A., B. C. Trapnell, P. L. Zeitlin, C. Montrose-Rafizadesh, B. J. Rosenstein, R. G. Crystal, and G. R. Cutting. 1991. Severe deficiency of cystic fibrosis transmembrane conductance regulator messenger RNA carrying nonsense mutations R553X and W1316X in respiratory cells of patients with cystic fibrosis. J. Clin. Invest. 88:1880-1885.

31. Zeitlin, P. L., I. Crawford, L. Lu, S. Woel, M. E. Cohen, M. Donowitz, M. H. Montrose, A. Hamosh, G. R. Cutting, D. Gruenert, et al. 1992. CFTR protein expression in primary and cultured epithelia. Proc. Natl. Acad. Sci. USA. 89:344-347.

32. Hamosh, A., B. J. Rosenstein, and G. R. Cutting. 1992. CFTR nonsense mutations G542X and W1281X are associated with severe reduction of CFTR nRNA. Ped. Pulm. Suppl. 8:253. (Abstr.)

33. Shosani, T., A. Sheinberg, A. Augarten, Y. Rivlin, A. Tal, E. Kerem, and B. Kerem. 1992. Normal mRNA levels in CF patients homozygous for the nonsense mutation W1282X. Ped. Pulm. Suppl. 8:245. (Abstr.)

34. Baserga, S., and E. J. Benz. 1988. Nonsense mutations in the human $\beta$-globin gene affect RNA metabolism. Proc. Natl. Acad. Sci. USA. 85:20562060.

35. Satoh, K., T. Nukiwa, M. Brantly, R. I. Garver, M. Ho f ker, M. Courtney, and R. G. Crystal. 1988. Emphysema associated with complete absence of $\alpha 1$-antitrypsin of a stop codon in an $\alpha 1$-antitrypsin-coding exon. Am. J. Hum. Genet. 42:77-83.

36. Kadowaki, S., H. Kadowaki, M. M. Rechler, M. Serrano-Rios, J. Roth, P. Gorden, and S. I. Taylor. 1990. Five mutant alleles of the insulin receptor gene in patients with genetic forms of insulin resistance. J. Clin. Invest. 86:254-264.

37. Lehrman, M. A., W. J. Schneider, M. S. Brown, C. G. Davis, A. Elhammer, D. W. Russell, and J. L. Goldstein. 1987. The Lebanese allele at the low density lipoprotein receptor locus: nonsense mutation produces truncated receptor that is retained in endoplasmic reticulum. J. Biol. Chem. 262:401-410.

38. Liebhaber, S. A., M. B. Coleman, J. G. Adams III, F. E. Cash, and M. H. Steinberg. 1987. Molecular basis for nondeletion $\alpha$-thalassemia in American black $\alpha 2^{116 G A G \rightarrow U A G}$. J. Clin. Invest. 80:154-159.

39. Fojo, S. S., P. Lohse, C. Parrott, G. Baggio, C, Gabelli, F. Thomas, J. Hoffman, and H. B. Brewer, Jr. 1989. A nonsense mutation in the apolipoprotein $\mathrm{C}^{-\mathrm{II}_{\mathrm{padova}}}$ gene in a patient with apolipoprotein C-II deficiency. J. Clin. Invest. 84:1215-1219.

40. Koehrer, K., and H. Domdey. 1991. Preparation of high molecular weight RNA. Methods Enzymol. 194:404-405.

41. Ward, C. L., M. E. Krouse, D. C. Gruenert, R. R. Kopito, and J. J. Wine. 1991. Cystic fibrosis gene expression is not correlated with rectifying $\mathrm{Cl}^{-}$channels. Proc. Natl. Acad. Sci. USA. 88:5277-5281.

42. Sambrook, J., E. F. Fritsch, and T. Maniatis. 1989. Analysis and cloning of eukaryotic genomic DNA. In Molecular cloning. 2nd edition. Cold Spring Harbor Laboratory Press, Cold Spring Harbor, NY., 7.43-7.45.

43. Gunning, P., P. Ponte, H. Okayama, J. Engel, H. Blau, and L. Kedes. 1983. Isolation and characterization of full length cDNA clones for human $\alpha-, \beta-$, $\gamma$-actin mRNAs: skeletal but not cytoplasmic actins have an aminoterminal cysteine that is subsequently removed. Mol. Cell. Biol. 5:787-795.

44. Trapnell, B. C., C. S. Chu, P. K. Paakko, T. C. Banks, K. Yoshimura, V. J. Ferrans, M. S. Cherenick, and R. G. Crystal. 1991. Expression of the cystic fibrosis transmembrane conductance regulator gene in the respiratory tract of normal individuals and individuals with cystic fibrosis. Proc. Natl. Acad. Sci. USA. 88:6565-6569.

45. Moll, R., W. W. Franke, D. L. Schiller, B. Geiger, and R. Krepler. 1983. The catalog of human cytokeratins: patterns of expression in normal epithelia, tumors, and cultured cells. Cell. 31:11-24.

46. Chalkey, G., and A. Harris. 1991. Lymphocyte mRNA as a resource for detection of mutations and polymorphisms in the CF gene. J. Med. Genet. 28:777-780.

47. Urlaub, G., P. J. Mitchell, C. J. Ciudad, and L. A. Chasin. 1989. Nonsense mutations in the Dihydrofolate gene affect RNA processing. Mol. Cell. Biol. 9:2868-2880.

48. Wine, J. J. 1992. No CFTR: are CF symptoms milder? Nature Genet. 1:10. 